Chitin Chemistry 


\section{CHITIN CHEMISTRY}

\section{GEORGE A.F. ROBERTS}

Senior Lecturer in Dyeing

Nottingham Polytechnic

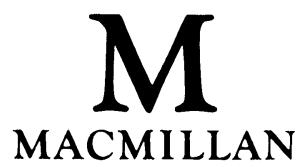


(C) George A.F. Roberts 1992

Softcover reprint of the hardcover 1st edition 1992

All rights reserved. No reproduction, copy or transmission of this publication may be made without written permission.

No paragraph of this publication may be reproduced, copied or transmitted save with written permission or in accordance with the provisions of the Copyright, Designs and Patents Act 1988, or under the terms of any licence permitting limited copying issued by the Copyright Licensing Agency, 90 Tottenham Court Road, London W1P 9HE.

Any person who does any unauthorised act in relation to this publication may be liable to criminal prosecution and civil claims for damages.

First published 1992 by

THE MACMILLAN PRESS LTD

Houndmills, Basingstoke, Hampshire RG21 2XS

and London

Companies and representatives

throughout the world

ISBN 978-1-349-11547-1

ISBN 978-1-349-11545-7 (eBook)

DOI 10.1007/978-1-349-11545-7

A catalogue record for this book is available from the British Library. 


\section{In memory of my parents}

\section{Isobel M.L. Roberts (née Gunion)}

(1904-89)

and

George A.E. Roberts

(1901-89) 


\section{Contents}

Foreword $\quad$ xi

Preface xii

Acknowledgements xiii

Glossary of Symbols and Abbreviations xiv

1. Structure of Chitin and Chitosan 1

1.1 Introduction 1

1.2 Nomenclature 6

$\begin{array}{ll}1.3 \text { Chemical structure } & 7\end{array}$

1.3.1 Historical background 7

1.3.2 The component monosaccharide(s) 10

1.3.3 Ring size and position of the glycoside bond 16

1.3.4 Stereochemistry of the glycoside bond 20

1.4 Physical structure 21

1.4.1 Introduction 21

1.4.2 Structure of $\alpha$-chitin $\quad 23$

1.4.3 Structure of $\beta$-chitin $\quad 30$

1.4.4 Structure of $\gamma$-chitin 33

1.4.5 Inter-relationships between $\alpha$-, $\beta$ - and $\gamma$-chitin 33

1.5 Chitin-protein complexes 35

1.5.1 Introduction 35

1.5.2 Evidence for covalent bonds between chitin and
protein

1.5.3 Nature of the chitin-protein link 38

1.5.4 Morphology of the chitin-protein complex 40

1.6 Physical structure of chitosan 43

1.6.1 Introduction 43 
1.6.2 Chitosan crystal structure $\quad 45$

References $\quad 49$

2. Preparation of Chitin and Chitosan 54

$\begin{array}{ll}2.1 \text { Sources of chitin } & 54\end{array}$

2.2 Purification $\quad 55$

2.2.1 Introduction $\quad 55$

2.2.2 Deproteinisation $\quad 55$

2.2.3 Demineralisation $\quad 57$

2.2.4 Decolouration $\quad 58$

2.3 Comparison of processing conditions 58

$\begin{array}{ll}2.4 \text { Chitin isolates } & 61\end{array}$

$\begin{array}{ll}2.4 .1 \text { Introduction } & 61\end{array}$

2.4.2 Residual protein $\quad 61$

2.4.3 Anomerisation $\quad 62$

2.5 Deacetylation of chitin $\quad 64$

$\begin{array}{ll}2.5 .1 \text { Introduction } & 64\end{array}$

2.5.2 Deacetylation by alkali fusion $\quad 65$

2.5.3 Deacetylation with aqueous alkali 65

2.5.4 Alternative techniques for deacetylation of chitin $\quad 69$

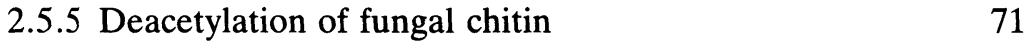

2.5.6 Fully deacetylated chitosan $\quad 73$

$\begin{array}{ll}\text { 2.5.7 Water-soluble chitosan } & 75\end{array}$

2.5.8 Changes in morphology during deacetylation 77

$\begin{array}{ll}2.6 \text { Preparation of pure chitin } & 80\end{array}$

2.7 Commercial preparation $\quad 81$

$\begin{array}{ll}\text { References } & 82\end{array}$

3. Analysis of Chitin and Chitosan 85

$\begin{array}{ll}3.1 \text { Introduction } & 85\end{array}$

3.2 Degree of $N$-acetylation $\quad 85$

3.2.1 Introduction $\quad 85$

3.2.2 Determination of the $N$-acetyl content 86

3.2.3 Determination of the amine group content 94

3.2.4 Determination based on overall composition $\quad 100$

$\begin{array}{ll}3.3 \text { Molecular weight } & 102\end{array}$

$\begin{array}{ll}3.3 .1 \text { Introduction } & 102\end{array}$

3.3.2 Light scattering spectrophotometry 103

3.3.3 Gel permeation chromatography $\quad 104$

$\begin{array}{ll}3.3 .4 \text { Viscometry } & 106\end{array}$

$\begin{array}{ll}3.4 \text { Other analyses } & 110\end{array}$

$\begin{array}{ll}3.4 .1 \text { Residual protein } & 110\end{array}$

$\begin{array}{ll}3.4 .2 \text { Colour } & 111\end{array}$

3.4.3 Percentage insoluble material 112 
3.4.4 Heavy metal content

3.4.5 Ash, lipids, moisture and nitrogen content 112 References

4. Derivatives of Chitin and Chitosan 116

4.1 Inorganic esters and related derivatives 116

4.1.1 Nitrates 116

$\begin{array}{ll}\text { 4.1.2 Phosphates } & 119\end{array}$

$\begin{array}{ll}\text { 4.1.3 Sulphates } & 121\end{array}$

4.1.4 Xanthates 130

4.2 Organic amides, esters and related derivatives 133

4.2.1 N-Acyl derivatives of chitosan 133

4.2.2 $O$-Acyl derivatives of chitin and its $N$-acyl analogues $\quad 147$

4.2.3 $O$-Acylation of chitosan and chitosan derivatives $\quad 158$

4.2.4 Simultaneous $N$ - and $O$-acylation of chitosan $\quad 159$

4.2.5 Arylcarbamate and arylureido derivatives $\quad 160$

4.3 Ethers and $N$-alkyl and $N$-aryl derivatives 162

4.3.1 Chitin ethers 162

4.3.2 Chitosan ethers $\quad 172$

4.3.3 N-Alkyl and $N$-aryl derivatives of chitosan $\quad 174$

4.3.4 Preparation of $N$-, $O$-carboxymethyl derivatives $\quad 184$

4.4 Schiff's base derivatives of chitosan 186

4.5 Miscellaneous derivatives $\quad 189$

4.5.1 Reaction with halogenated heterocyclic ring systems $\quad 189$

4.5.2 Tosyl and trityl derivatives 191

4.5.3 Trimethylsilyl derivatives of chitin 195

References 196

5. Chemical Behaviour of Chitin and Chitosan 203

5.1 Acid-base properties of chitin and chitosan 203

5.2 Complex formation with metal ions 206

5.2.1 Introduction 206

5.2.2 Influence of chemical and physical structure 206

5.2.3 Studies on chitosan-metal ion complexation 211

5.2.4 Complex formation with fungal chitin and chitosan 214

5.2.5 Structure of chitosan-metal ion complexes 216

5.2.6 Complex formation by derivatives of chitin and
chitosan

5.3 Adsorption on chitin and chitosan 229

5.3.1 Adsorption of dyes 229

5.3.2 Adsorption of proteins 238

5.3.3 Adsorption of aromatic hydrocarbons 241

5.3.4 Adsorption of other chemical substances 242

5.3.5 The use of chitin and chitosan in chromatography 244 
$\begin{array}{ll}5.4 \text { Degradation of chitin and chitosan } & 249\end{array}$

$\begin{array}{ll}\text { 5.4.1 Acid hydrolysis } & 249\end{array}$

$\begin{array}{ll}\text { 5.4.2 Alkaline degradation } & 254\end{array}$

5.4.3 Deamination and chain scission with nitrous acid 257

$\begin{array}{ll}5.4 .4 \text { Biodegradation } & 261\end{array}$

$\begin{array}{ll}\text { References } & 267\end{array}$

6. Solubility and Solution Behaviour of Chitin and Chitosan 274

$\begin{array}{ll}6.1 \text { Solubility } & 274 \\ & 6.1 .1\end{array}$

$\begin{array}{ll}\text { 6.1.1 Solubility of chitin } & 274\end{array}$

$\begin{array}{ll}\text { 6.1.2 Solubility of chitosan } & 278\end{array}$

6.1.3 Solvent compatibility $\quad 281$

6.1.4 Electrolyte tolerance $\quad 281$

$\begin{array}{ll}6.2 \text { Solution properties } & 292\end{array}$

6.2.1 Chitin solutions $\quad 292$

6.2.2 Polyelectrolyte nature of chitosan in acid solution 293

6.2.3 Conformation and molecular dimensions of chitosan chains in acid solution $\quad 295$

6.2.4 Rheology of concentrated chitosan solutions 300

6.2.5 Chitosan-induced metachromasy 303

$\begin{array}{ll}6.3 \text { Gelation } & 305\end{array}$

6.3.1 N-Acylchitosan gels 305

6.3.2 N-Alkylidene- and $N$-arylidenechitosan gels 309

6.3.3 Thermally reversible gels 313

6.4 Adsorption of chitosan from solution 315

6.4.1 Adsorption of chitosan on cellulose 315

6.4.2 Adsorption on inorganic dispersions 318

6.4.3 Adsorption on organic dispersions 320

$\begin{array}{ll}\text { References } & 325\end{array}$

$\begin{array}{ll}\text { Subject Index } & 330\end{array}$

$\begin{array}{ll}\text { Author Index } & 339\end{array}$ 


\section{Foreword}

Chitin is the second most important natural polysaccharide (cellulose being the first). But fundamental knowledge about chitin and its applications is frequently difficult to obtain.

Even though its original and spectacular properties have been recognised for a long time (it was first isolated by Braconnot in 1811), it seems that no great uses were made of these until comparatively recently.

The first review of chitin was presented by R. Muzzarelli in 1977. Subsequently, International Symposiums on Chitin and Chitosan kept the information up to date. Chitin Chemistry answers the needs of people working in this field as well as those who want to develop new products for specific applications. The book gives an exhaustive overview of chitin and its derivatives. Both the solid state and the solution properties of chitin and chitosan are discussed.

The book is a very useful source of knowledge for everyone involved with chitin and its developments.

Professor M. Rinaudo

University Joseph Fourier of Grenoble 


\section{Preface}

Although the isolation of chitin by Braconnot in 1811 preceded Payen's isolation of cellulose by some 30 years, the development of the chemistry of chitin and its industrial applications has lagged far behind that of cellulose. However the 1970s saw the beginning of an upsurge of interest in chitin chemistry, spearheaded by the publication of Professor Muzzarelli's two books, Natural Chelating Polymers (1973) and Chitin (1977), and the organisation of the 1st International Conference on Chitin/Chitosan in 1977. In the intervening period the chemical behaviour of these polymers has been studied intensively and the object in writing this book is to present an up-to-date, ordered, coherent and critical account of the chemistry of chitin and chitosan.

As indicated by the title, the book is concerned with the chemistry of these polymers and no attempt has been made to deal with their biology except for two topics, the chitin-protein complexes of native chitin and the biodegradation of chitin and chitosan, whose inclusion seemed particularly relevant. Furthermore, despite the considerable interest that exists in the commercial utilisation of the two polymers, their possible applications have not been discussed apart from a few brief references. Although there is a large and ever-increasing number of potential uses proposed for these polymers and their derivatives, particularly in the patent literature, most would appear not to be in use at the present time and I did not feel in a position to find the few needles in the numerous haystacks. However it is my hope that this book, by presenting a comprehensive account of their chemistry, may point the way to the development of useful applications for these most intriguing polymers. 


\section{Acknowledgements}

My interest in chitin developed out of an earlier interest in cellulose and I am indebted to Dr Hal S. Blair of Queen's University, Belfast, who first introduced me to cellulose chemistry, and to Mr Eugene D. Klug who further stimulated my interest in it during the period that I was fortunate to work with him at Hercules Inc. I am also indebted to my former research students - Drs Graham K. Moore, Julian G. Domszy, Beryl D. Gummow, Ghobad G. Maghami, Kathryn E. Taylor and Ing. Irineu Batista - whose work has contributed much to my understanding of chitin.

My thanks are due to Drs Joan C. Halfpenny and Neil A.A. MacFarlane, both of Nottingham Polytechnic, for interesting discussions and helpful comments on aspects of X-ray crystallography and of biology respectively, and to Dr Keith D. Parker of Leeds University for reading the complete manuscript and for his constructive comments.

My most sincere thanks are due to Mrs Frances A. Wood, Nottingham Polytechnic, not only for typing the manuscript, preparing the Figures, organising the Indexes and helping with correction of the proofs, but also for the valuable technical support that she has given my research students and myself over many years. 


\title{
Glossary of Symbols and Abbreviations
}

\author{
$a$ \\ AA \\ Am \\ BSA \\ CD \\ C.I. \\ CMC \\ CP/MAS \\ CS \\ CSA \\ CSC \\ DCA \\ DCC \\ DD \\ DEAE cellulose \\ DIPEA \\ DMAc \\ DMF \\ DMSO \\ DNA \\ DNase \\ DNFB \\ $D P$ \\ $\overline{D P}_{\mathrm{n}}$ \\ $\overline{D P}_{\mathrm{v}}$ \\ $\overline{D P}_{\mathrm{w}}^{\mathrm{v}}$ \\ exponent in the Mark-Houwink equation \\ alginic acid \\ Kuhn statistical chain element \\ bovine serum albumin \\ circular dichroism \\ Colour Index (published by the Society of Dyers and \\ Colourists) \\ carboxymethyl cellulose \\ cross polarisation/magic angle spinning \\ cellulose sulphate \\ chondroitin sulphate A \\ chondroitin sulphate $\mathrm{C}$ \\ dichloroacetic acid \\ dicyclohexylcarbodiimide \\ degree of deacetylation \\ diethylaminoethyl cellulose \\ di-(prop-2-yl)ethylamine (di-isopropylethylamine) \\ dimethylacetamide \\ dimethylformamide \\ dimethylsulphoxide \\ deoxyribonucleic acid \\ deoxyribonuclease \\ 2,4-dinitrofluorobenzene \\ degree of polymerisation \\ number-average degree of polymerisation \\ viscosity-average degree of polymerisation \\ weight-average degree of polymerisation \\ xiv
}


DS

DxS

EDTA

EO

ESR

FTIR

GC

GCD

GC/MS

GLC

GPC

GTMAC

GUA

HA

HECh

HEP

HMPA

IPA

IR

K

LC

LVN

$\bar{M}_{\mathrm{n}}$

$\bar{M}_{\mathrm{v}}$

$\bar{M}_{\mathrm{w}}$

MCA

$M S$

MWD

NADH

NASA

NCA

NMP

NMR

NSA

Py

RNA

RNase

SEM

TBA

TCA

TEA

THF

TLC

UV degree of substitution

dextran sulphate

ethylenediaminetetraacetic acid $\left(\mathrm{Na}^{+}\right.$salt $)$

ethylene oxide

electron spin resonance

Fourier transform infra-red

gas chromatography

glycidol (2,3-epoxypropanol)

gas chromatography/mass spectroscopy

gas-liquid chromatography

gel permeation chromatography

glycidyltrimethylammonium chloride

poly(galacturonic) acid

hyaluronic acid

hydroxyethyl chitosan

heparin

hexamethylphosphoramide

2-propanol (iso-propanol)

infra-red

constant in the Mark-Houwink equation

liquid chromatography

limiting viscosity number

number-average molecular weight

viscosity-average molecular weight

weight-average molecular weight

monochloroacetic acid

moles of substitution

molecular weight distribution

nicotinamide adenine dinucleotide (reduced form)

1-naphthylamine-4-sulphonic acid

$\mathrm{N}$-carboxyanhydride

$\mathrm{N}$-methyl-2-pyrrolidone

nuclear magnetic resonance

1-naphthol-4-sulphonic acid

pyridine

ribonucleic acid

ribonuclease

scanning electron microscopy

2-methyl-2-propanol (tert-butanol)

trichloroacetic acid

triethylamine

tetrahydrofuran

thin-layer chromatography

ultra-violet 
xvi

$[\eta]$

$\eta_{\text {(inh) }}$

$\eta_{\text {sp/c }}$
GLOSSARY OF SYMBOLS AND ABBREVIATIONS

limiting viscosity number (formerly intrinsic viscosity) logarithmic viscosity number (formerly inherent viscosity)

viscosity number (formerly reduced viscosity) 